\title{
Preliminary Study on Cavernicolous Insecta Community in Tasikmalaya Karst Area, West Java
}

\author{
Isma Dwi Kurniawan ${ }^{1}$, Intan Lupida Diana Susila², Ida Kinasih ${ }^{3}$, Iman Aulia Rahman ${ }^{4}$, \\ Ridwan Nasrullah ${ }^{5}$ \\ \{ismadwikurniawan@uinsgd.ac.id, tan.lupida@gmail.com, idakinasih@uinsgd.ac.id, \\ imanauliarahman95@gmail.com, nasrullah.geo@gmail.com\} \\ Department of Biology, Faculty of Science and Technology, UIN Sunan Gunung Djati Bandung 1,2,3,4 \\ Indonesian Speleological Society ${ }^{1,5}$ \\ Caves society ${ }^{5}$
}

\begin{abstract}
Tasikmalaya district has a large karst area with many potential caves. Up to the present, subterranean biodiversity in this karst area was still poorly understood. This project aimed to investigate the diversity and abundance of cave-dwelling insecta also abiotic parameters in three selected caves located in Tasikmalaya karst area. Insecta samplings were conducted in each cave zonation (entrance, twilight and dark zones) by hand collecting, pitfall traps, and Berlese extractors. Abiotic parameters including light intensity, air temperature, relative humidity (RH), soil temperature, soil moisture, and soil $\mathrm{pH}$ were also measured. In total 1142 individuals grouped into 9 orders, 19 families and 37 morphospecies were collected during the study. All species were considered as troglophile. The diversity was dominated by Hymenoptera (32\%) and Coleoptera (30\%), meanwhile the abundance was dominated by Hymenoptera (30\%), Blattodea $(28 \%)$, and Orthoptera (21\%). Richness and diversity indices were greater in entrance and twilight zones compared to dark zone, while evenness index was varying among communities. Camel cricket (Rhaphidophoridae) and Cockroach (Family: Blattidae and Blaberidae) were dominant in the dark zone. Abiotic parameters were varying within cave zonation. Light intensity and soil $\mathrm{pH}$ were higher in entrance and twilight zones compared to dark zone, otherwise air temperature, $\mathrm{RH}$, soil temperature, and soil moisture were higher in the dark zone. Richness and diversity were positively correlated with light intensity and soil $\mathrm{pH}$ but negatively correlated with air temperature, $\mathrm{RH}$, soil temperature and soil moisture.
\end{abstract}

Keywords: Cave, diversity, abundance, insecta, microclimate, inventory

\section{Introduction}

Caves are a unique environment with typical environmental characters. This environment is indicated by the absent of sunlight which is the main source of energy for all living systems in this planet. The other specific characters of this environment are their microclimate stability, saturated relative humidity, lack of $\mathrm{O}_{2}$ concentration, and limited amount and variation of organic materials[1][2]. Such extreme conditions prohibit many critters to be able to life in caves. Only particular species which are successfully adapted to such condition that can occupy this domain. Those species are commonly known as "cavernicolous" which means cave-dwelling organisms[3]. 
Arthropod is a group of fauna that is predominant in caves[3]. One of this group members, Class Insecta, is fascinating since they are the most diverse group compared to the other groups based on some previous studies. Some dominant Insecta's orders like Coleoptera, Hymenoptera, Hemiptera, and Diptera are common in Indonesian caves[4][5][6][7]. Instead of their diversity, some other orders are great in abundance such as Lepidoptera (immature stage), Blattodea and Orthoptera[4][7][8]. Their diversity and abundance imply to their role in ecosystem. Insecta is one of the major groups that are dominant in cave's food web so their presence is intensely important in maintaining cave ecosystem stability.

Tasikmalaya district which is located in West Java Province has a large karst area with many caves. Atleast 500 caves occur in approximately 158.301 ha of the karst area situated at the southern part of this district. Up to the present, the biology of those caves was still received little attention and poorly understood. Scientific publications related to subterranean biodiversity of this karst area were also very limited.

The continuity of caves ecosystem in Indonesia has several serious threats. Many caves are exploited for economic benefits, such as phosphate mining, swift nest exploitation, and bats hunting[9]. Some other caves are developed into show caves[10][11][12]. Extractive industry particularly limestone quarrying for cement has also become a major threat for cave ecosystems[13]. Those activities are also found in Tasikmalaya which potentially disappearing caves biodiversity before they are studied.

In order to provide data about cave biodiversity of the karst area, survey should be carried out. This study aimed to investigate the diversity and abundance of cavernicolous Insecta in several caves located in Tasikmalaya karst area. We also measured abiotic parameters of each cave to understand their habitat conditions.

\section{Methods}

\subsection{Study Sites}

This study was conducted at 3 selected caves located in Tasikmalaya karst area. They

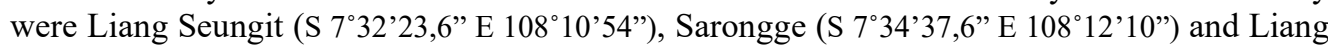
Boeh (S $7^{\circ} 32^{\prime} 20,1^{\prime \prime}$ E $\left.108^{\circ} 10^{\prime} 56,2^{\prime \prime}\right)$. The caves were chosen purposively based on their similar characters in which all were horizontal, fossil caves, and situated in adjacent site one another. All samplings were conducted in each cave zonation, starting from entrance zone, twilight zone, and dark zone.

\subsection{Insecta Collection}

Collection was performed through 3 different techniques. They were hand collecting, pitfall traps, and Berlese extractors. Hand collecting was conducted by helps of gloves, tweezers, and brushes in 30 minutes for each cave zonation. Pitfall traps were made by vial bottles $(5 \mathrm{~cm}$ in diameter, filled by $70 \%$ alcohol and glycerin with $9: 1$ in ratio) and established 5 pieces in each cave zonation for 2 days. Approximately, 1 liter of soil samples were taken from each cave zonation and extracted for 5 days in Berlese extractor tunnels. All collected samples were preserved in $70 \%$ alcohol, labelled, and identified under stereo microscope based on morphological characters up to the lowest possible taxon level.

\subsection{Abiotic Measurements}


Several abiotic parameters were measured during the study. They comprised light intensity, air temperature, relative humidity, soil temperature, soil moisture, and soil $\mathrm{pH}$. All parameters were measured directly in the field during sampling periods. Measurements were conducted in each cave zonation with 3 repetitions for every parameter.

Data Analysis

All recorded data were displayed in table and graph then analyzed descriptively. Three kinds of ecological indices were used in this study, they were richness (Margalef), diversity (Shannon-Wiener), and evenness (Pielou) indices. Sorensen similarity index was also used to show the similarity of Insecta diversity among cave communities. Spearman rank correlation analysis was carried out in order to know the relations among measured variables. The analysis was performed in RStudio software.

\section{Result and Discussion}

\subsection{Characteristic of the studied caves}

Liang Seungit is located in Parung village, Cibalong subdistrict. It possessed a large entrance and passage but relatively short $(61.445 \mathrm{~m})$. This cave was inhabited by two groups of bats, namely insectivorous bats (Microchiroptera) and frugivorous bats (Megachiroptera). Bat populations were found in the twilight zone and majority aggregated in the dark zone. Although Liang Seungit was a wild cave, but it had experienced various degree of human disturbances. This cave had frequently explored by humans for different objectives. For instance, meditation and tourism. Vandalism and trash accumulation were easily found in this cave's passage.

Sarongge is located in Urug village, Kawalu subdistrict. It possessed relatively complex passages with two dark zones which were located in opposite direction with total length of 100 $\mathrm{m}$. There was a water penetration in the dark zone which generated several water puddles. Insectivorous bats appeared in the dark zones with a great abundance. Entrance zone was surrounded by vegetation, essentially Bambusa sp. This cave was recently developed into show cave by local residents. There were several artificial transformations on its structure, including vegetation clearing and installation of walkways in the entrance zone. Human disturbances found in this cave were bats hunting, phosphate mining, tourism, and meditation activities.

Similar to Liang Seungit, Liang Boeh is also located in Parung village. This cave had a small entrance surrounded by plants, mostly ferns and mosses. Liang Seungit possessed a simple passage with total $100.658 \mathrm{~m}$ in length. Great abundance of insectivorous bats was roosting in the dark zone. Beside of insectivorous bats, some vertebrates including snakes and frogs also could be found in this cave. This cave was also frequently explored by humans, mostly for phosphate mining and meditation purposes.

\subsection{All recorded morphospecies}

In total 1.141 individuals of Insecta belonging to 9 orders, 19 families and 37 morphospecies were collected during the study. The detail is presented in Table 1. 
Table 1. Recorded taxa in all caves

\begin{tabular}{|c|c|c|c|}
\hline Order & Family & Number of Morphospecies & Number of Individual \\
\hline \multirow[t]{2}{*}{ Blattodea } & Blaberidae & 1 & 314 \\
\hline & Blattidae & 1 & \\
\hline \multirow[t]{5}{*}{ Coleoptera } & Cisidae & 1 & 21 \\
\hline & Eucnemidae & 1 & \\
\hline & Nitidulidae & 1 & \\
\hline & Scaphidiidae & 1 & \\
\hline & Staphylinidae & 7 & \\
\hline Dermaptera & Anisolabididae & 1 & 4 \\
\hline \multirow[t]{3}{*}{ Diptera } & Drosophilidae & 1 & 42 \\
\hline & Phoridae & 1 & \\
\hline & Psychodidae & 2 & \\
\hline \multirow[t]{2}{*}{ Hemiptera } & Enicocephalidae & 1 & 161 \\
\hline & Miridae & 2 & \\
\hline \multirow[t]{2}{*}{ Hymenoptera } & Chalcidoidea & 1 & 340 \\
\hline & Formicidae & 11 & \\
\hline \multirow[t]{2}{*}{ Orthoptera } & Gryllidae & 1 & 238 \\
\hline & Rhaphidophoridae & 1 & \\
\hline Psocoptera & Unidentified & 1 & 14 \\
\hline Lepidoptera & Tineidae & 1 & 7 \\
\hline
\end{tabular}

All recorded insecta's orders from all caves are well known to have caves representative[3][14][15]. According to some previous studies[4][5][7][8], those group were commonly found in Javanese caves. Almost all families were also familiar in cave realm, except Cisidae, Miridae, and Chalcidoidea. These families seemed restrictedly distributed. All morphospecies recorded in this study were considered as troglophile because none from them depicted high degree of troglomorphy, the specific adapted character to life in caves[16]. Several morphospecies which are familiar such as camel cricket (Rhaphidophora sp.) and cockroach (Blattidae) actually have a long antenna and relatively thin cuticle, but they were not classified as troglobite (cave obligate species) since they were also found apart from caves[9][17]. 


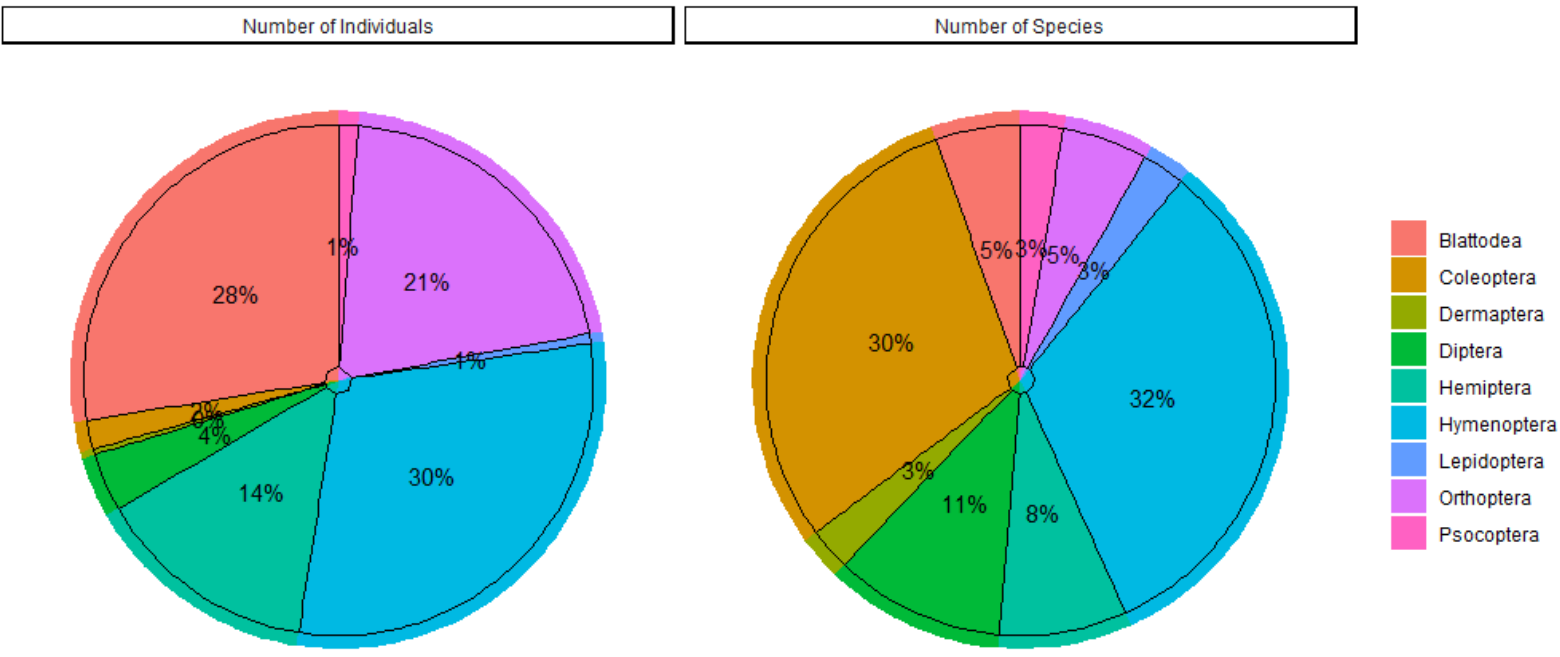

Fig 1. Proportion of species diversity and abundance based on order

Depending on their order, several groups were dominant as good as in term of species diversity and or their abundance. Hymenoptera (12 species) and Coleoptera (11 species) were dominating in species diversity. The combination of both orders contributed to more than $60 \%$ of the whole species richness in all caves. From both groups, Formicidae and Staphylinidae were immense with 11 species and 7 species respectively. The majority of Formicidae were collected in entrance and twilight zones, while Staphylinidae in twilight and dark zones. Coleoptera is common in subterranean realm. They are one of the most adapted groups to life in caves[3][16]. Staphylinidae is one of successful family capable of inhabiting cave, both as troglophile or troglobite[4][18][19]. In the other hand, a few species of Hymenoptera particularly Formicidae were reported to be troglobite. They seem to act as troglophile or accidental.

In the term of abundance, Hymenoptera (340 individuals), Blattodea (314 individuals), and Orthoptera (238 individuals) were the dominant groups. Similar to their diversity, Hymenoptera's abundance was also dictated by Formicidae which is well known as eusocial insect[20]. Their presence in colony made this group were captured in a large number through pitfall trapping, particularly in entrance zone. Two families of Blattodea, Blattidae and Blaberidae, were abundant in twilight and dark zones. Blaberidae were easily found spreading in the cave floor of Liang Seungit, while Blattidae were monopolized cave wall in Sarongge. Camel cricket (Rhaphidophoridae) as Orthoptera representative was abundant in the dark zone of all caves. Rhaphidophoridae is one of the most familiar and successful insects to occupy cave habitat, also has importance roles in cave ecosystem as one of food sources for other cave-dwelling faunas [3][16].

\subsection{Community structure in cave zonation}

Caves environment were generally divided into 3 main zones according to their microclimate characters[1] [9]. As the consequences, the diversity and abundance of Insecta in 
each zone are also different[4][21]. Figure 2 shows the distinction on richness, diversity and evenness values among each cave zonation.
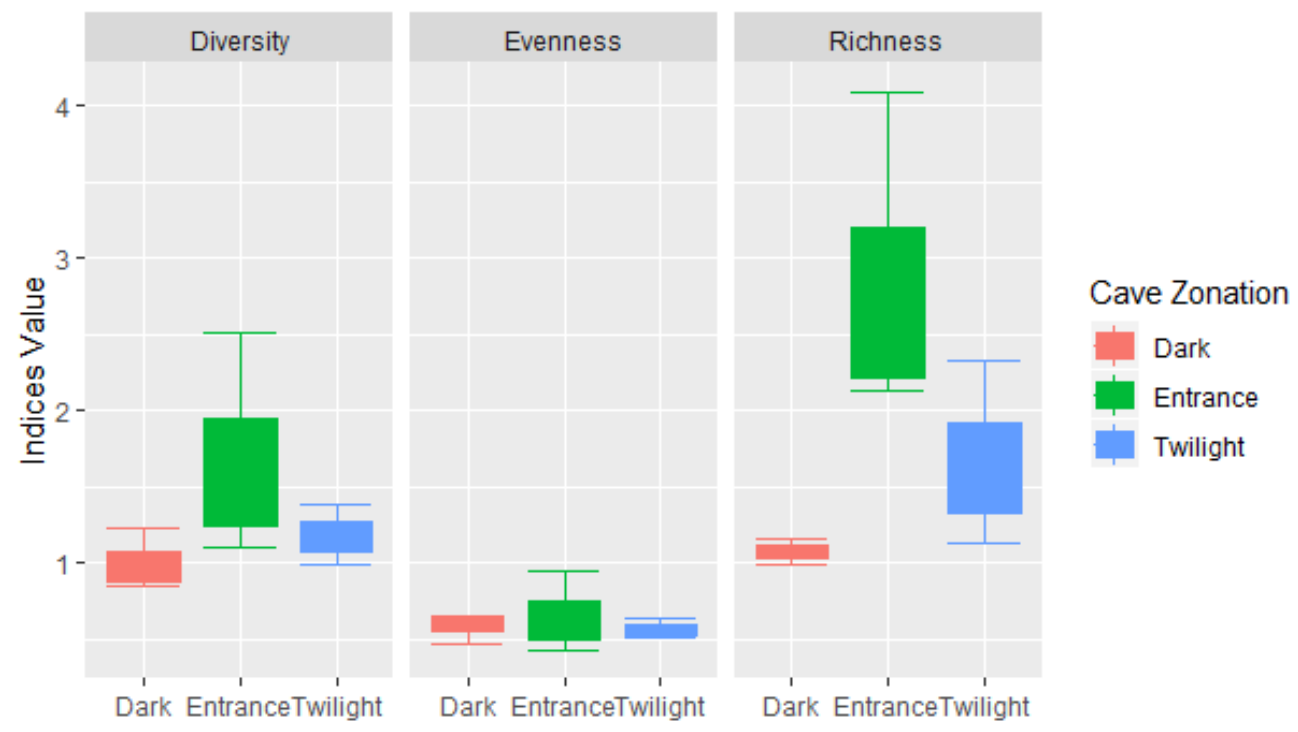

Fig 2. Diversity, evenness, and richness values in each cave zonation.

As seen in Figure 2, diversity and richness values demonstrated a similar pattern. Both indices value was greater in entrance and twilight zones, compared to the dark zone. This result was similar to several previous studies which also mentioned that species richness and diversity will commonly decline with the addition of distance from the cave entrance[4][21]. Environmental conditions in entrance and twilight zones can support many critters to survive because sunlight and primary producer still present. In contrast, dark zone has relatively extreme conditions that inhibit many species to occupy this site [3][9][16]. Only a few species capable of survive in this zone, and several of them particularly troglophile groups will have extremely large in abundance such as Rhaphidophoridae and Blattidae (Fig. 3). 


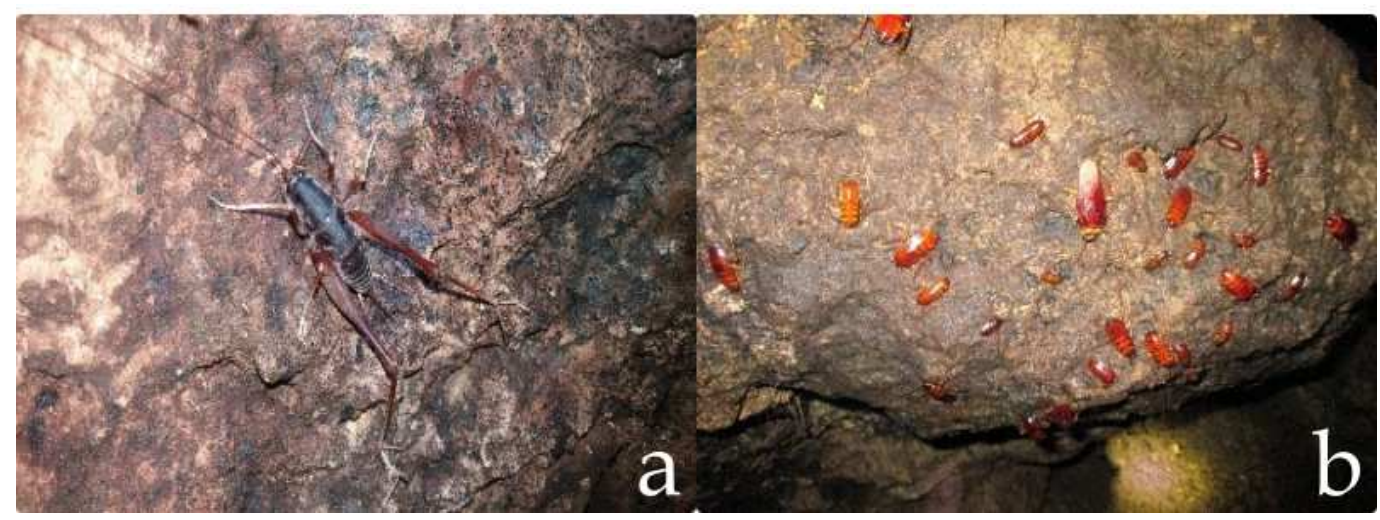

Fig 3. Species with great abundance in dark zone. a) Camel cricket (Rhaphidophoridae), and b) Cockroach (Blattidae).

Evenness value was varying among cave zones. Evenness is negatively correlated with domination. It can be used to explain species domination in a particular community. As seen in Figure 2, It was likely that species domination could occur in every cave zone, even the twilight and dark zones were relatively higher. Low evenness value of entrance zone occurred in Sarongge and Liang Seungit, these sites were predominated by ant populations (Subfamily: Ponerinae and Myrmicinae). For twilight zone, low evenness values were found in Sarongge and Liang Seungit. A capsid bug (Hemiptera: Miridae) and a cockroach (Blaberidae) were dominating these sites respectively. Meanwhile, the dark zones in all caves were dominated mainly by camel cricket (Rhaphidophoridae), also by two different cockroaches, Blattidae in Sarongge and Blaberidae in Liang Seungit. Alongside camel cricket, cockroach is also well known as abundant group of Insecta in caves[22]. Furthermore, several species were also reported as troglobite. For instance, the giant cave cockroach from east Borneo Miroblata baii [23].

\subsection{Similarity among communities}

Similarity index is used to analysis the likenesses of species composition among cave zonation. The result of Sorensen similarity index measurement is presented in Table 2. Bold numbers indicate a high degree of similarity between two compared communities.

Table 2. Sorensen's similarity index among communities

\begin{tabular}{|c|c|c|c|c|c|c|c|c|c|}
\hline & SE & ST & SD & BE & BT & BD & LE & LT & LD \\
\hline SE & 1 & & & & & & & & \\
\hline ST & 0,75 & 1 & & & & & & & \\
\hline SD & 0,333 & 0,3 & 1 & & & & & & \\
\hline BE & 0,48 & 0,519 & 0,286 & 1 & & & & & \\
\hline BT & 0,235 & 0,211 & 0,154 & 0,3 & & & & & \\
\hline
\end{tabular}




\begin{tabular}{|c|c|c|c|c|c|c|c|c|c|}
\hline BD & 0,133 & 0,118 & 0,182 & 0,111 & 0,4 & 1 & & & \\
\hline LE & 0,333 & 0,385 & 0,3 & 0,37 & 0,211 & 0 & 1 & & \\
\hline LT & 0,25 & 0,222 & 0,167 & 0,211 & 0,182 & 0,222 & 0,222 & 1 & \\
\hline LD & 0,375 & 0,222 & 0,333 & 0,211 & 0,182 & 0,222 & 0,222 & 0,8 & 1 \\
\hline $\begin{array}{l}S= \\
B= \\
L= \\
E= \\
T= \\
D=\end{array}$ & $\begin{array}{l}\text { arongg } \\
\text { iang B } \\
\text { iang S } \\
\text { intranc } \\
\text { wiligh } \\
\text { Dark zo }\end{array}$ & $\begin{array}{l}\text { eh } \\
\text { ungit } \\
\text { zone } \\
\text { zone } \\
\text { e }\end{array}$ & & & & & & & \\
\hline
\end{tabular}

As seen in Table 2, high similarity values were found between SE and ST (0.75), BE and ST (0.519), also LT and LD (0.8). According to this result, it could be inferred that twilight zone might be similar to both entrance and dark zones. Several previous studies indicated that twilight zone community had a higher similarity to dark zone instead of entrance zone, but they used Bray Curtis similarity index which consider the number of individuals of each species alongside the presence and absence of the species[4][21]. Twilight zone is an ecotone which became the border between epigean (outside cave) and hypogean (inside cave). The species compositions of this zone are generally combination between outside and inside caves habitat[24]. Several species also would only stay in this zone temporary that makes species composition in this zone driving apparently.

\subsection{Environmental parameter}

As might be expected, the gradation on environmental parameters occurs in all studied caves. Table 3 shows the mean of environmental parameters measured in every cave zonation. Light intensity as the main parameter distinguishing caves zonation was decline in twilight zone and absent in dark zone. Soil pH also possessed similar pattern. Entrance and twilight relatively bore more basic $\mathrm{pH}$ compared to dark zone which possessed acidic $\mathrm{pH}$. Dark zones of all caves were used by insectivorous bat's population as roosting sites. Guano piles produced by bats inside caves passage contribute to the soil acidity. Fresh bats guano is generally to be more basic, but becomes more acidic when older[25]. Bats guano is rich in organic material content which acts as the most important food source for cave-dwelling fauna in tropical caves[3][9][16].

Table 3. The mean of environmental parameters measurement

\begin{tabular}{lrrrrrr}
\hline Community & \multicolumn{1}{c}{$\begin{array}{c}\text { Soil } \\
\text { Temp. }\left({ }^{\circ} \mathbf{C}\right)\end{array}$} & Soil Moist. (\%) & $\begin{array}{c}\text { Air Temp. } \\
\left({ }^{\circ} \mathbf{C}\right)\end{array}$ & RH (\%) & Light Int. (lux) & Soil pH \\
\hline Sarongge (E) & 23,67 & 52 & 23,17 & 83 & 361,33 & 6,1 \\
Sarongge (T) & 25,33 & 86 & 24,37 & 95 & 10 & 5,8 \\
Sarongge (D) & 26 & 100 & 25,27 & 98 & 0 & 5,63 \\
Boeh (E) & 22,67 & 76 & 23,87 & 86 & 73,67 & 6,47 \\
Boeh (T) & 22 & 85 & 22,6 & 96 & 2,67 & 5,77
\end{tabular}




\begin{tabular}{lrrrrrr} 
Boeh (D) & 24 & 98 & 25,6 & 96 & 0 & 5,43 \\
Seungit (E) & 23 & 72 & 26,6 & 82 & 108 & 7 \\
Seungit (T) & 22 & 72 & 24,47 & 93 & 3,33 & 7 \\
Seungit (D) & 23 & 83 & 26,53 & 96 & 0 & 5,57 \\
\hline
\end{tabular}

In contrast to light intensity and soil $\mathrm{pH}$, the rest of parameters had an opposite pattern. Soil temperature, soil moisture, air temperature, and relative humidity all were higher in the dark zone. Relative humidity and soil moisture were extremely high (above $80 \%$ for soil moisture, and above $90 \%$ for $\mathrm{RH}$ ). Saturated humidity is one of the typical cave environment characters[1]. Air temperature and soil temperature in the dark zone were also higher. Dark zone is an isolated passage that shows cave specific environmental condition. This site is lack of microclimate fluctuation so temperature and humidity are relatively stable[3][17].

\subsection{Correlation between Insecta community structure and environmental parameters}

The occurrence of Insecta communities cannot be separated from abiotic conditions surrounding them. The relations between richness, diversity, and evenness of Insecta with measured environmental parameters in each cave zonation are presented in Table 4. Bold numbers are indicated as strong and significant correlation between two compared parameters.

Table 4. Coefficient of correlation among environmental parameters with Insecta community

\begin{tabular}{ccccccc}
\hline Indices & $\begin{array}{c}\text { Soil } \\
\text { Temp. }\end{array}$ & $\begin{array}{c}\text { Soil } \\
\text { Moist. }\end{array}$ & $\begin{array}{c}\text { Air } \\
\text { Temp. }\end{array}$ & RH & $\begin{array}{c}\text { Light } \\
\text { Intensity }\end{array}$ & pH \\
\hline Richness & $\mathbf{- 0 . 5 6 3}$ & $\mathbf{- 0 . 7 0 3}$ & -0.433 & $\mathbf{- 0 . 6 6 1}$ & $\mathbf{0 . 6 9 5}$ & $\mathbf{0 . 8 5 4}$ \\
Diversity & $\mathbf{- 0 . 8 2 3}$ & $\mathbf{- 0 . 6 9 5}$ & -0.033 & $\mathbf{- 0 . 6 1 0}$ & 0.441 & $\mathbf{0 . 6 9 5}$ \\
Evenness & -0.471 & 0.159 & 0.067 & 0.084 & -0.254 & -0.176 \\
\hline
\end{tabular}

Richness and diversity indices were positively correlated with light intensity and soil $\mathrm{pH}$. Entrance zone was contributing a great number of species diversity in all three caves. This zone possessed a higher light intensity and soil $\mathrm{pH}$ compared to dark zone. The presence of sunlight and higher soil $\mathrm{pH}$ (6-7) support many critters to survive. Even arthropods are well known as one of soil fauna that are tolerant to acidity[26], but it is likely that many Insecta species in caves prefer place with neutral $\mathrm{pH}$ to acidic one. In the other hands, richness and diversity possessed negative correlation with the rest of environmental parameters. According to this study, many Insecta preferred passages with lower temperature and humidity in caves.

Insecta is an ectothermic fauna that highly depends on their surrounding temperature. Each species has its maximum and minimum temperature thresholds[27]. Higher temperature in dark zone seemed to be one of inhibition to their presence. Similarly, Insecta also has humidity thresholds. Insecta and other arthropods are generally sensitive to desiccation. Wet environment will protect them since they possess a large body surface relative to their body volume[28]. Their eggs also require wet condition for efficient hatching[29]. But saturated humidity is also reported to be one of detrimental condition to many Insecta because it leads pathogens and diseases development which can decrease their population[28]. 


\section{Conclusion}

In conclusion, Tasikmalaya has rich in cave-dwelling Insecta. The diversity was dominated by Hymenoptera (32\%) and Coleoptera (30\%), meanwhile the abundance was dominated by Hymenoptera (30\%), Blattodea (28\%), and Orthoptera $(21 \%)$. Entrance and twilight zones possessed greater in Insecta diversity and abundance compared to dark zone. Twilight zone was an ecotone which had species combination between entrance and dark zones. Caves environmental parameters were varying within cave zonation. Light intensity and soil $\mathrm{pH}$ were higher in entrance and twilight zones compared to dark zone, otherwise air temperature, RH, soil temperature, and soil moisture were higher in the dark zone. Richness and diversity were positively correlated with light intensity and soil $\mathrm{pH}$ but negatively correlated with air temperature, RH, soil temperature and soil moisture.

\section{Acknowledgement}

The authors are thankful to Caves Society and Indonesian Speleological Society for their help during survey and data collections. To colleagues in Museum Zoologicum Bogoriense, Indonesian Institute of Science (LIPI) for providing many references. To reviewers for helpful comments in improving the manuscript.

\section{References}

[1] D. C. Culver and W. B. White, Encyclopedia of Caves Second Edition, 2nd ed. USA: Elsevier Academic Press., 2012.

[2] J. Gunn, Encyclopedia of Caves and Karst Science. New York: Routledge Taylor and Francis Group, 2004.

[3] A. Romero, Cave Biology Life in Darkness. New York: Cambridge University Press, 2009.

[4] I. D. Kurniawan, R. C. H. Soesilohadi, C. Rahmadi, R. E. Caraka, and B. Pardamean, "The difference on Arthropod communities 'structure within show caves and wild caves in Gunungsewu Karst area , Indonesia,” Ecol. Environ. Conserv., vol. 24, no. 1, pp. 72-81, 2018.

[5] T. B. P. Prakarsa and K. Ahmadin, "Diversitas Arthropoda Gua di kawasan Karst Gunung Sewu, Studi gua-gua di Kabupaten Wonogiri,” BIOTROPIC J. Trop. Biol., vol. 1, no. 2, pp. 31-36, 2017.

[6] C. Rahmadi, “Cave Fauna of Java,” Bogor, 2008.

[7] C. Rahmadi, "Keanekaragaman Arthropoda di Gua Ngerong, Tuban, Jawa Timur," Zoo Indones., vol. 29, pp. 19-27, 2002.

[8] M. Kamal, I. Yustian, and S. Rahayu, "Keanekaragaman Jenis Arthropoda di Gua Putri dan Gua Selabe Kawasan Karst Padang Bindu, OKU Sumatera Selatan,” J. Penelit. Sains, vol. 14, no. 1, pp. 33-37, 2011.

[9] O. T. Moldovan, L. Kovac, and S. Halse, Cave Ecology. Switzerland: Springer, 2018.

[10] I. D. Kurniawan, C. Rahmadi, T. E. Ardi, R. Nasrullah, M. I. Willyanto, and A. Setiabudi, "The Impact of Lampenflora on Cave-dwelling Arthropods in Gunungsewu Karst, Java, Indonesia," Biosaintifika, vol. 10, no. 22, pp. 275-283, 2018.

[11] I.D. Kurniawan; C. Rahmadi; T. E. Ardi; R. Nasrullah; M. I. Willyanto; and S. Rahayu, Proceedings of the 17th International Congress of Spelology, 2nd ed., vol. 1, no. 2. Sydney, 2017.

[12] A. Fernandez-Cortes et al., "Detection of human-induced environmental disturbances in a show cave,” Environ. Sci. Pollut. Res., vol. 18, no. 6, pp. 1037-1045, 2011. 
[13] N. M. Furey and P. A. Racey, "Conservation Ecology of Cave Bats," in Bats in the anthropocene: Conservation of bats in a changing world, 1st ed., V. Christian and K. Tigga, Eds. Switzerland: Springer, 2016, pp. 463-500.

[14] P. Beron, "Comparative study of the invertebrate cave faunas of Southeast Asia and New Guinea," Hist. Nat. Bulg., vol. 21, pp. 169-210, 2015.

[15] T. K. Philips, C. S. DeWildt, H. Davis, and R. S. Anderson, "Survey of the terrestrial arthropods found in the caves of Ghana," J. Cave Karst Stud., vol. 78, no. 2, pp. 128-137, 2016.

[16] D. Culver and T. Pipan, The Biology of Caves and Other Subterranean Habitats. New York: Oxford University Press, 2009.

[17] Y. R. Suhardjono and R. Ubaidillah, Fauna Karst dan Gua Maros Sulawesi Selatan. Jakarta: LIPI Press, 2012.

[18] G. Sabella, E. Amore, and G. Nicolosi, "A new troglobitic Tychobythinus from Sicily (Coleoptera, Staphylinidae, Pselaphinae),”Zootaxa, vol. 4567, no. 2, pp. 379-386, 2019.

[19] A. Asenjo, T. Pietrobon, and R. L. Ferreira, "A new troglobitic species of Metopioxys (Staphylinidae: Pselaphinae) from Brazilian iron ore caves," Zootaxa, vol. 4576, no. 1, pp. 195200, 2019.

[20] M. S. Holm, "Evolution of Eusociality in Mole-Rats,” Honor. Theses, vol. 431, pp. 1-10, 2017.

[21] I. D. Kurniawan, C. Rahmadi, R. E. Caraka, and T. E. Ardi, "Short Communication : Cavedwelling Arthropod community of Semedi Show Cave in Gunungsewu Karst Area , Pacitan , East Java , Indonesia," Biodiversitas, vol. 19, no. 3, pp. 857-866, 2018.

[22] W. J. Bell, L. M. Roth, and C. A. Nalepa, Cockroaches. USA: The Johns Hopkins University Press, 2007.

[23] P. Grandcolas and L. Deharveng, "Miroblatta baai, a new very large cockroach species from caves of Borneo (Blattaria: Blaberidae)," Zootaxa, vol. 1390, pp. 21-25, 2007.

[24] X. Prous, R. Lopes Ferreira, and R. Parentoni Martins, "Ecotone delimitation: Epigean-hypogean transition in cave ecosystems," Austral Ecol., vol. 29, no. 4, pp. 374-382, 2004.

[25] R. L. Ferreira, X. Prous, and R. P. martins, "Structure of bat guano communities in a dry Brazilian cave," Trop. Zool., vol. 20, pp. 55-74, 2007.

[26] P. Lavelle, A. Chauvel, and C. Fragoso, "Faunal activity in acid soils," in Plant Soil Interactions at Low pH, R. A. Date, N. J. Grundon, G. E. Rayment, and M. E. Probert, Eds. Netherlands: Kluwer Academic Publishers, 1995, pp. 201-211.

[27] A. F. G. Dixon, A. Honek, P. Keil, M. A. A. Kotela, A. L. . Izling, and V. Jarosík, "Relationship between the minimum and maximum temperature thresholds for development in insects," Funct. Ecol., vol. 23, pp. 257-264, 2009.

[28] F. B. Masika, M. Masanza, G. Aluana, A. F. Barrigossi, and E. B. Kizito, "Abundance , distribution and effects of temperature and humidity on arthropod fauna in different rice ecosystems in Uganda,” J. Entomol. Zool. Stud. 2017;, vol. 5, no. 5, pp. 964-973, 2017.

[29] A. Khaliq, M. Javed, M. Sohail, and M. Sagheer, "Environmental effects on insects and their population dynamics," J. Entomol. Zool. Stud., vol. 2, no. 2, pp. 1-7, 2014. 